\title{
Klasik Gitarda Sol El Serçe Parmağı ile Legato Tekniği Üzerine Bir Değerlendirme
}

DOI: $10.26466 /$ opus. 873382

\author{
Okay Özdağ * \\ * Dr. Öğr. Üyesi, İskenderun Teknik Üniversitesi, Hatay/Türkiye \\ E-Posta: okay.ozdag@iste.edu.tr \\ ORCID: $\quad$ 0000-0002-7614-6562
}

\section{Öz}

Müzik aletlerinin neredeyse tamamı, el ve parmakların aktif bir şekilde kullanılmasıyla çalınmaktadır. Genelde çalgı çalmak ve bazı özel meslekler dışında insanlar günlük hayatlarında tüm parmaklarını aktif olarak kullanmadığından, parmakların kontrollü küçük kas hareketlerinin gerekli olduğu durumlarla karşılaştıkları zaman bu konuda zorluk yaşamaktadırlar. Klasik gitar çalgısı da tüm parmakların aktif bir şekilde kullanılması gereken bir çalgıdır. Klasik gitar çalan çalgıcılar da günlük hayatlarında sık kullanmadıkları parmakları etkin bir şekilde kullanmaları gerektiğinde, bu konu karşılarına bir problem olarak çıkmaktadır. Bu çalışmada klasik gitar çalarken en sık karşılaşılan problemlerden biri olan sol el serçe parmă̆ının kas ve kontrol açısından zayıflı̆̆ının giderilmesine yönelik çözüm önerileri ele alınmıştır. Bu problemin en çok legato tekniği uygularken karşımıza çıkması sebebiyle legato tekniği üzerinden serçe parmağının yeterli kas oranına ve uygun kontrol seviyesine ulaşması amacıyla legatonun ve ters legatonun aşamalara bölünerek nasıl çalışılması gerektiği ele alınmıştır. Serçe parmağının etkin kullanımına yönelik çözüm önerilerinin yanı sıra gitar tarihi ve eğitimine, el anatomisi ve motor beceri konularına da kısaca değinilmiştir. Bu çalışmanın amacı gitaristlere sol el serçe parmağı özelinde fakat her parmakta karşılaşan bu problemi nasıl aşacaklarına ilişkin fikir sunmaktır.

Anahtar Kelimeler: Gitar, Legato, Serçe parmak, Sol el. 
ISSN:2528-9527

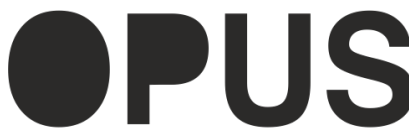

E-ISSN: 2528-9535

Yıl Year: 11

Cilt Volume: 18

Sayı Issue :40

Uluslararası Toplum Araştırmaları Dergisi

International Journal of Society Researches

Ağustos August 2021

Makalenin Geliş Tarihi Received Date: 02/02/2021

Makalenin Kabul Tarihi Accepted Date: 06/04/2021

\title{
An Evaluation on Legato Technique with Left Hand Little Finger in Classical Guitar
}

\begin{abstract}
Almost all of the musical instruments are played with the active use of hands and fingers. People do not use their fingers actively in their daily life except for while playing musical instruments and doing some special profession. So when they encounter situations where they have to control small muscles movements of the fingers are required, they have difficulties in this issue. Also, classical guitar is an instrument in which all fingers must be actively used. When classical guitar players need to effectively use fingers which they do not use frequently in their daily life, this issue comes up as a problem. In this study, solution and suggestions for eliminating the weakness of the left hand little finger which is one of the most common problems while playing classical guitar in terms of muscle and control are discussed. Guitar players are mostly encountered with this problem while applying the legato technique. So we discuss how legato and reverse legato should be worked by dividing them into stages in order to reach the sufficient muscle structure and appropriate control level of the little finger over the legato technique. In this study, we mention about the history and education of the guitar, hand anatomy and motor skills are also briefly mentioned in addition to suggestions for effective use of the little finger. The aim of the this study is to provide an idea to guitarist on how to overcome this problem which is not only specific to the left hand little finger but also in every finger.
\end{abstract}

Keywords: Guitar, Left hand, Legato, Little finger. 


\section{Giriş}

Telli çalgıların tarih sahnesinde görülmeye başlamasından bu yana teknolojinin de gelişmesiyle orantılı olarak gitar çalma tekniklerinde de yenilikler ve değişiklikler olmuştur. Söz konusu yenilik ve değişiklikler teknolojinin gelişmesinin yanı sıra ulusal akımlardan, farklı coğrafyalardaki yerel müzik icra tekniklerinden, dans ritimlerinden, çalgının yapıldığı malzemelerden de etkilenmiştir. İcra tekniklerinden biri olan legato tekniği de bu gelişmelerden şüphesiz ki etkilenmiş ve sonuç olarak daha etkin bir şekilde kullanılmaya başlanmıştır. Tüm çalgılar için ayrı dönemlerden eserleri incelediğimizde legato tekniğinin sıklıkla karşımıza çıktığını görmekteyiz. Neredeyse bütün müzik formlarında yer yer legato tekniğiyle çalınması istenen müzik cümleleri karşımıza çıkmaktadır. Tamamen legato tekniğiyle çalınması istenen eserler de mevcuttur. Son yüzyılda dijital teknolojinin de gelişmesiyle, elektronik müzik alanında legato tekniğinin sıklıkla kullanıldığını söyleyebiliriz. Bilgisayarla yapılan müziklerde de aynı durum söz konusudur. Bu denli sıklıkla kullanılan legato tekniğinin klasik gitar icrasında legato kullanılan eserlerin ilgili pasajlarının tekrar edilmesinin yanında daha etkin ve yetkin uygulanabilmesi için uygun ve verimli egzersizleri bulmak bir ihtiyaç haline gelmiştir. Çalg1 ailesine bağlı olarak legato tekniği küçük farklılıklar barındırsa da temelde aynı amaç ile tanımlanmaktadır. Az enerji ile çok verim elde etmeye yönelik teknik egzersizler, zamanın hızlı aktığı, karşılık olarak verimin hemen beklenildiği günümüzde daha da aranır hale gelmiştir. Kişiye ve şartlara bağlı olarak değişkenlik gösteren verimlilik unsuru legato tekniğinin icrasını geliştirmek için de geçerlidir. İstisnai durumlar haricinde legato tekniğinde kullanılan parmak ve el kaslarının ideal bir şekilde gelişimini sağlayacak egzersizler genel geçer kabul edilebilir.

\section{Klasik Gitarın Kısaca Tarihi}

Tarih içerisinde ilk kez Batı Asya medeniyetlerinde rastlanan gitara benzer telli çalgıların daha sonraları Mısırlılar, Romalılar ve Asurlularda görüldügü, özellikle Haçlı seferlerinin kültürel alanındaki etkileri sonucunda çalgının Araplar tarafından Avrupa'ya yayıldığı 
düşünülmektedir. Gitarın kökenine inildiğinde en eski telli çalgılardan biri olarak kabul edilen Lir ve benzeri enstrümanlarla başlayan çalgının gelişimini hızla devam ettirdiği ortaya çıkmaktadır. Bugün klasik gitarın adının bir çeşit lir olan eski kitaralardan geldiği ancak çalgının kökeninin eski "Lavta" ve "Pandoura" tipi telli çalgılara dayandığı en kuvvetli görüş olarak kabul edilmektedir (Halvaşi, 1999).

İlk çağlardan beri Sümerliler, Eski Mısırlılar, Asurlar, Babilliler, Yunanlılar ve Romalılarda rastlanan 'Lut' diğer ismiyle 'Lavta' gitarın öncüsü olarak bilinen enstrümanlardan biridir. "Armut şekilli gövdesi ve bombeli sırtı ile lavta Araplara ait "ud" un akrabasıdır" (Chapman, 1999).

“Gitara benzer enstrümanlar 12. ve 13. yüzyıl Fransa ve İspanya katedrallerindeki kabartmalarda da görülmüştür. Bu enstrümanlar İspanya'da guitarra morisca ve guitarra latina olarak iki ayrı adla bilinmektedir" (Yöndem, 2003).

"Klasik gitar 18. yüzyılda bazı önemli besteciler sayesinde gelişmeye başlamıştır. D. Aguado, M. Giulliani ve F. Sor gibi sanatçılar belirgin bir teknik virtüözite gerektiren müzik eserleri üretmişlerdir" (Chapman, 1999).

19. yüzyıl boyunca gitarın popülerliği artmış, yeni çalım teknikleri geliştirilmiş ve repertuvarına yeni parçalar eklenmiştir. İspanyol besteci ve gitarist Fransisco Tarrega hem icracı hem de eğitmen olarak o güne kadar klasik müzik içinde bestelenmiş birçok eseri gitara uyarlamıştır (Elmas, 1994).

Günümüzde kullandığımız biçemiyle "klasik gitar", 1860'l1 yıllarda ortaya çıkmıştır. Ancak bu tarihten önce de özellikle Avrupa'da kimi gitar olarak adlandırılan, kimi de farklı isimlere sahip fakat şekil olarak klasik gitara benzeyen birçok çalgı kullanılmıştır. Bu yönüyle klasik gitarın, kendinden önceki çağlarda kullanılan bütün gitar benzeri çalgıların evrim sürecinden geçerek ulaştı̆̆ olduğunu söyleyebiliriz (Uluocak, 2011).

\section{Klasik Gitar Eğitimi}

20. yüzyılın ilk yarısından itibaren tüm dünyada büyük bir hızla yaygınlık kazanan klasik gitar, ülkemizde de giderek beğeni kazanmış, 
zamanla müzik kültürümüz içinde kendine özgü bir yer edinmiştir. Günümüzde genel, özengen ve mesleki müzik eğitiminin her aşamasında etkin olarak kullanılan klasik gitar, müzik eğitimi ve kültürüne katkı sağlayan çalgılardan biridir (Akt. Uluocak, 2015).

1977'de Mimar Sinan Üniversitesi Devlet Konservatuarı'nda, 1983'te de Marmara Üniversitesi Müzik Eğitimi Bölümü’nde klasik gitar eğitimi verilmeye başlanması da Türkiye' de klasik gitar eğitiminin örgün eğitim kurumları aracılığıyla bilinçli, sistemli bir şekilde gelişmesini sağlamış ve yaygınlaşmasına destek olmuştur. Tüm bu gelişmelerin tarihlerine bakıldığında ülkemizde klasik gitarın 1970'lerde yaygınlaşmaya başladığı görülür. Klasik gitarda çalım üslubu açısından hem sol el parmakları hem de sağ el parmakları çok daha aktiftir. Klasik gitar müziği armonik kurallara göre iç içe geçmiş ezgiler bütününden oluşur. Bu şekilde çok sesli bir ezgiyi çalabilmek için hem sağ el parmaklarının hem de sol el parmaklarının tümü aynı anda karmaşık bir sistemle kullanılır. Böyle bir çalım yetisine ulaşmak için de düzenli, disiplinli ve nispeten uzun bir öğrenim süreci gerekir (Kasar ve Yöndem, 2006).

Elmas'a (1994) göre, gitarı öğrenebilmek için her şeyden önce gitarı sevmek ve öğrenmeye karşı istekli bir tavır sergilemek gerekmektedir. Ayrıca gitar öğrenecek kişinin el yapısı, parmak ve tırnak yapısı başta olmak üzere, fiziki durumu gitar çalmaya uygun olmalıdır. Bunların ayrı olarak, her öğrenci çalışarak belirli bir ilerleme kat edebilir, fakat gitarı iyi çalabilmek için yetenek şarttır. Öğrencinin sahip olduğu yetenek düzeyi (müzik kulağı, ritim duygusu) öğrenim sürecine etki eder. Gitar öğrenmek isteyen bir birey, sistemli ve planlı bir çalışma düzenini içerisinde kararlı ve sabırlı bir şekilde çalışmalarını gerçekleştirmelidir (Ak, 2018).

\section{El Anatomisi ve Motor Beceri}

El oldukça kompleks bir anatomik yapıya sahip olup el anatomisi denilince kemikler, eklemler, ligamentler ve kasların yanı sıra ele ilişkin deri ve subkutan doku ve bölgede yer alan damar ve sinir yapılar da akla gelmelidir. Etkili çalma tekniği uygun zamanlarda gerginliği az olan kaslara sahip olmaya bağlıdır. Etkili bir teknik için gerekli olan kas gevşemesi bilinçsiz bir süreç içinde gerçekleşir. Uygun kas kasılma ve 
gevşemeleri sonucu motor beceri oluşur. Motor beceri müzik eğitimi boyunca zamanla artar. Müzik performansı düzenli egzersizler ve işitsel geri bildirim ile beyindeki motor ve duyusal alanlarının birleştirilmesi sonucu ortaya çıan otomatikleşmiş, kompleks sensoriomotor sistemin bir ürünüdür. Müzik için gerekli olan tempo, ses seviyesi, ton ve tını gibi unsurların ustalıkla gerçekleşebilmesi için gerekli olan algısal beceri ile kazanılmış yeni motor becerilerin entegrasyonu el ve kolda birçok eklemin organize bir şekilde çalışmasını gerektirir. Devamlı yapılan pratikler sonucu el hareketleri yavaş yavaş bir motor programa dönüşür ve kas hafızası oluşur. Uzun bir süre tekrarlanan ardışık hareketler uzun süreli kas hafızasını oluşturur ve bu da bilinçli çaba gerektirmeden performansın ortaya çıkmasını sağlar. Gerekli tempo ve sesi üretmek için ihtiyaç duyulan kas gücü ve eklem hareket açıları parmakları tuşlara dokunmak için hazırlar. Böylece tekrarlı geçişler boyunca el ne kadar uzağa konumlanacağını bilir ve bu da motor hareketlerin ardışık bir şekilde otomatik olarak gerçekleşmesini sağlar. $\mathrm{Bu}$ süreç motor hareketlerin tempo, dinamik, eklemin biçimlendirilmesi ve ardışık motor hareketlere entegrasyonunu içerir (Akt. İzci, 2019).

\section{Gitarda Sol El}

Klasik gitarda sağlak bir çalıcı için sol el, gitarın klavyesindeki perdeler aracılığıyla gitar telinin uzunluğunu ayarlayarak istenilen notanın çalınmasına olanak sağlayan eldir. Solak bir gitarist için ise bu durum tam tersidir. Başparmak gitarın sapının arkasında destek amaçlı kullanılmaktadır. İşaret parmağı birinci parmak, orta parmak ikinci parmak, yüzük parmağ üçüncü parmak ve serçe parmak da dördüncü parmak olarak belirtilir. Sağ elde ise başparmak " $p$ ", işaret parmağ " $i$ ", orta parmak " $\mathrm{m}$ ", yüzük parmağı "a" harfleri kullanılarak belirtilmektedir. Klasik gitarda sağ el serçe parmak her ne kadar sık kullanılmasa da "e"," s","c, "x" harfleriyle belirtildiği görülmüştür.

\section{Legato Tekniği}

Legato tekniğinin gelişiminden söz etmek için, öncelikle 'bağ' işaretinin gelişim sürecini ifade etmek yerinde olacaktır. Kim (2002), legato 
artikülasyonun kaynağını vokal müzik ve teknikten aldığını, enstrümanlar arasında yaylı çalgıların legatoyu belirten sembol olarak bağı ilk kabul eden grup olduğunu, ardından tahta üfleme çalgılarının kabul ettiğini, klavyeli çalgıların ise bu sembolü benimsemelerinin çok daha yavaş gerçekleştiğini ifade etmiş̧tir. Chew (2001b) de, 16. yüzyıldan itibaren bağın özellikle tek bir hecede söylenen notalar için kullanıldığını, enstrümantal müzikte ortaya çıkmasının uzun zaman aldığını, pek çok notanın ya da pasajın bağsız olmasının eserlerin yanlış yorumlanmasına sebep olduğunu, 18. yüzyıldan itibaren bağın yaygın hale gelmesiyle birlikte bazı bestecilerin, özellikle de J. S. Bach'ın (16851750) legatoyu belirtmek için bağ işaretini sıklıkla kullandığını belirtmiştir (Akt. Çoban, 2019).

Legato, tüm enstrümanlarda müziğin doğası gereği akıc1, duygusal, dramatik, şarkı söylermişçesine ifadelerde kullanılan bir yay çalım tekniğidir. Yaylı çalgılarda ardı ardına yazılmış notaları tek yayda çalmak olarak ifade edilmektedir. Ayrıca legato tek yayda çalmaktan ziyade, legato olarak yazılmış olan sesleri birbirine kaynaştırarak çalmak olarak da tanımlanabilir. İcracı legatoda, öncelikle müziği iyi okuyabilmeli, müzik cümlelerinin nerede başlayıp nerede bittiğini ya da hangi cümlelerin ana, hangilerinin yardımcı cümleler olduklarını dikkatli analiz ettikten sonra müziği akışına bırakmalıdır. legatolu eserleri yorumlama sırasında, icracı mekaniğe ihtiyaç duysa da kendini müziğin akışına bırakmalıdır. Müzik ancak bu durumda bir doyuma ulaşacaktır. Teknik, müzikte sadece bir araç olmalı ve hiçbir zaman müzikalitenin önüne geçmemelidir. Legatoda, uzun müzik cümlelerinden kaynaklanan sorunların başında tel değişimi de gelmektedir. Sorunsuz bir tel geçişi için üç temel prensip bulunmaktadır: Bunlardan birincisi aynı ritimde; ikincisi aynı nüansta; üçüncüsü ise tel geçişleri sırasında iki nota arasında aksan oluşmamasıdır. Teller arasında geçiş yapıldığı kesinlikle hissedilmemelidir (Araboğlu, 2011).

Klasik gitar repertuvarına baktı̆̆ımız zaman legato tekniği birçok eserde karşımıza çıkmaktadır. Eserleri doğru şekilde icra edebilmek için de bu tekniği doğru şekilde yapmak önemlidir. 


\section{Sol El Serçe Parmağını Kullanmadaki Zorluklar}

İnsan doğal olarak, yaratılışından ötürü ellerinin en çok başparmak ve işaret parmağını kullanmaktadır. Klavyede yazı yazarken, bir objeyi tutarken, anahtarla bir yeri açarken ve daha birçok işi yaparken baş ve işaret parmağın daha çok kullanıldığını görebiliriz. Kullanım sıklığı orta, yüzük ve serçe parmağında diğer iki parmağa oranla daha azdır. Bu parmakları olan diğer canlılar incelendiğinde başparmak ve işaret parmaklarının daha güçlü ve daha çok kullanıldığı gözlemlenebilir. Bu beş parmak arasında en az kullandığımız parmağın serçe parmak olduğunu rahatlıkla söyleyebiliriz. Bu yüzden bu parmaktaki kas gelişimi de diğer parmaklara oranla oldukça zayıftır. Yalnızca kas olarak değil, parmağı kontrol etme becerimiz de diğer parmaklara göre daha zayıftır. Tüm telli çalgılarda olduğu gibi Klasik gitarda sol elde serçe parmağı etkin bir şekilde kullanmak oldukça gereklidir. Kas ve kontrol yönünden yetersiz olan bu parmağı gitarda aktif olarak kullanma gerekliliği karşımıza zorluk olarak çıkmaktadır. Gitar çalmaya başladığınız yıla kadar çok aktif olarak kullanılmayan bu parmağı kas ve kontrol bakımından geliştirmek gerekmektedir. Diğer parmaklar yakın ve diğer parmaklarla uyumlu bir şekilde çalışabilen bir duruma getirmemiz gerekmektedir. Bunun için o parmağı pasif durduğu yılları telafi edecek ölçüde metodik ve kontrollü olarak aktif çalıştırılması gerekmektedir.

\section{Legato tekniği ile zorlukların çözüm önerileri}

Legato tekniği ile ilgili karşılaşılan bu zorlukları aşmak için yapılması gereken öncelikle serçe parmağın pasif olarak kullanılan kaslarını uygun düzeyde geliştirmek olacaktır. Bunun için legato tekniğinde gerekli olan hareket üzerine yoğunlaşarak o hareketi yavaşça periyodik olarak tekrarlamak gereklidir. Legato tekniğinde iki durum karşımıza çıkmaktadır. Birincisi kalın notadan ince notaya olan legatodur, ikincisi de; ince notadan kalın notaya olan legatodur. Birinci legato şekline "çekiç" adı verilir.

Legato hareketini dört aşamaya bölüp yavaşça çalışmak oldukça verimli olacaktır. Bu aşamalar şu şekildedir: 
1. Parmağın klavyeden uzak bir şekilde gergince durduğu aşama: Legato tekniği uygularken harcadığımız gücü (tele uyguladığımız basınç) 100 birim üzerinden değerlendirecek olursak bu aşamada kullanılmaya hazır beklettiğimiz potansiyel 100 birim enerjimiz vardır.

2. Gergin parmağın, telin perdedeki uygun yerine çekiç misali vurduğu aşama: $\mathrm{Bu}$ aşama bu gücün uygulanma noktasına taşındığ aşama olacaktır.

3. Parmağın çalınan ikinci nota üzerinde gergince durduğu aşama: $\mathrm{Bu}$ aşama 100 birim basınç gücünü tel üzerine uyguladığımız aşamadır.

4. Parmağın çalınan nota üzerinde sesin devamını sağlayacak gerginlikte fakat parmağın tel ile ilk temasındaki gerginlikten biraz daha gevşetildiği aşama: $\mathrm{Bu}$ aşama sağlıklı sesin devam edebilmesi için gerekli olan asgari (en az) basınç gücünü bulmamız ve uygulamamız gereken aşamadır. Bu aşamada basıncın fazla olması çalgıcıya gereksiz güç kaybı yaşatacak ve çalgıcıyı yoracaktır. Basıncın gereğinden az olması durumunda ise tel iyice titreşemeyeceği için sağlıklı bir ses elde edilemeyecektir.

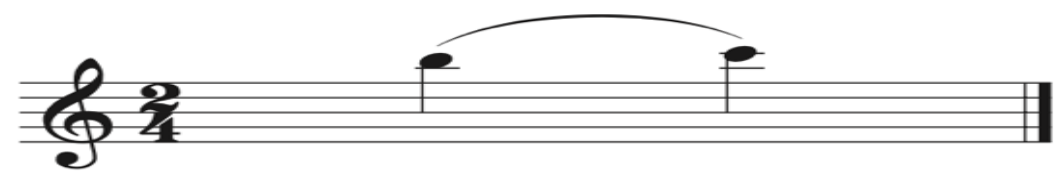

Şekil 1. Legato

Ters legato için de dört aşama şu şekildedir:

1. Notanın çalındığı, sol elin serçe parmağının tel üzerinde durduğu aşama: Yukarıda belirtilen 100 birim gücün tamamının değil, tasarruf yapılarak telden sağlıklı bir ses çıkacak asgari seviyede güç uygulandığı aşamadır.

2. Serçe parmağın gitarın klavyesine basınç uygulayarak teli aşağ 1 doğru çekip bıraktığı aşama: Bu aşamada telden ses çıkaracak olan serçe parmak, sağlıklı sesi çıarabilmek için 100 birim güce ihtiyaç duyacaktır. 
3. Parmağın klavyeden gergince uzaklaştı̆̆ı aşama: Varsayılan 100 birim gücü uyguladıktan sonra tele tekrar temas edip üretilen sesi bozmayacak kadar uzaktaki bir noktaya konumlandığı bir aşamadır.

4. Parmağın gergin olan kaslarını bilinçli şekilde gevşettiğimiz aşama: $\mathrm{Bu}$ aşama da 1. Aşama gibi güçten tasarruf edilen bir aşamadır. 100 birim gücü elde etmek için daha önceden kasılmış olan kasların uygun parmak pozisyonunu bozmayacak kadar gevşetildiği aşamadır.

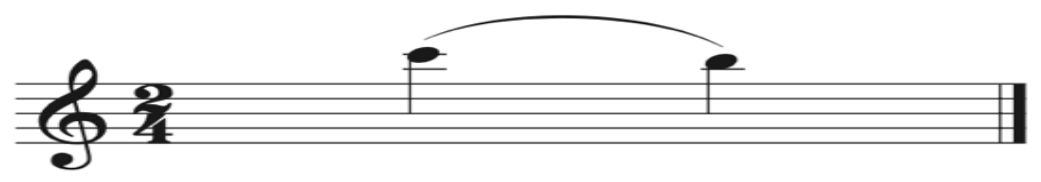

Şekil 2. Ters Legato

Çalgıcıyı en az yoracak fakat telden de sağliklı bir ses elde edebileceğimiz ideal gücü uygulama motor becerisinin kazanılması önemlidir. Genelde görmezden gelinen, üzerine pek düşünülmeyen ya da farkında olunmayan bu aşamalarda, tasarruf ettiğimiz basınç gücü çalgıcıyı rahatlatacak, yorulmamasına yardımcı olacak, el, bilek ve ön kol ile ilgili ağrı ve sakatlanmaların meydana gelme ihtimalini azaltacaktır. Orta ve uzun soluklu eserlerin çalınmasını daha mümkün kılacaktır. Çalgıcının kondisyonunun daha dengeli ve uzun süreli verimli olabilmesine yardımcı olacaktır. Bu dört aşamayı hem müzikal hem de psikomotor yönden kavrayan bir çalgııı daha önceden ne kadar gereksiz güç kaybettiğinin farkına varacaktır.

$\mathrm{Bu}$ dört aşamayı sırasıyla yavaşça ve odaklanarak yapmak, serçe parmağın kaslarının gelişmesini ve parmak üzerindeki kontrol becerimizin artmasına çokça katkı sağlayacaktır. Bu egzersizlerin gitar çalmaya başlamadan önce yapılması alışkanlık haline getirilmelidir. Klasik gitar edebiyatındaki eserlere çalışırken karşımıza çıkan legato kısımlarına odaklanıp, eserin o pasajını bir egzersiz materyali haline getirip bu dört aşamayı uygulamak da serçe parmağın legato tekniği açısından işlevini artıracaktır. 


\section{Tartışma ve Sonuç}

İnsan doğduğundan bu yana çok ihtiyacı olmadı̆̆ 1 için nadiren kullandığı serçe parmak klasik gitar ile eser icrasında oldukça önemli bir yere sahiptir. Genellikle telli çalgılarda sapa yaslanarak destek olarak kullanılan baş parmak dışında diğer işaret, orta, yüzük ve serçe parmaklar tele dokunup ya da baskı uygulayıp sesin şekillenmesini sağlayan parmaklardır. Bu dört parmağın etkili ve verimli bir şekilde koordine olarak kullanılması çalgı üzerindeki hakimiyeti artıran en önemli faktörlerden biridir. Güç ve kontrol açısından zayıf ve verimsiz olan serçe parmak, diğer parmakların performansı yanında oldukça geride kalmaktadır. Serçe parmağın bu eksik yönü diğer parmaklar verimli olsa bile çalgı hakimiyeti açısından bir sorun olmaktadır. Çalgı için yazılmış eserlerin icrasında da serçe parmağın kullanılması gereken yerler oldukça, bu eserler çalgıcı için çalınması daha zor olmaktadır ya da mümkün olmamaktadır. Serçe parmağın özel bir durum olmadıkça nadiren kullanılmasının bir sonucu olarak serçe parmağın kaslarının pasif ve kontrol açısından zayıf olması klasik gitar ve bütün telli çalgıları çalma konusunda aşılması gereken bir zorluk olarak hemen karşımıza çıkıyor. Legato tekniği de serçe parmağını aktif ve verimli bir şekilde kullanmamız gereken bir tekniktir. Klasik gitarda legato tekniği için ihtiyacımız olan problemli ve kontrolsüz harekete odaklanarak ve bu hareketi yavaşlatıp aşamalara bölerek ve her bir aşamayı kavrayarak yapmak bu problemi çözmedeki en etkili yöntemlerden biridir. Serçe parmak için önerilen bu yöntemler sol elin diğer parmakları için de uygulanabilir. İki notadan oluşan legato tekniği için kullanılacak parmakların kendi aralarında kombinasyonunun uygulanarak yapılması tüm parmakların gelişimi için faydalı olacaktır. Bu öneriler gerekirse küçük uyarlamalarla, parmakların aktif olarak kullanıldığı tüm çalgılar için geçerlidir. Birçok alanda olduğu gibi müzik alanında da hedeflenen davranışı öğrenmek için belirli bir zaman zarfına ihtiyacımız olacaktır. $\mathrm{Bu}$ zaman zarfı tabii ki kişiden kişiye değişir. Fakat bu yöntemin işlevsellik kazanması ve olumlu sonuçlarının görülmesi herkes için orta ve uzun vadeli bir durumdur denilebilir. 


\section{EXTENDED ABSTRACT}

\section{An Evaluation on Legato Technique with Left Hand Little Finger in Classical Guitar \\ * \\ Okay Özdă̆ \\ İskenderun Technical University}

The aim of this study is to prevent the little finger, which is one of the most common problems with the hands and fingers, which we need to use effectively and efficiently in almost all musical instruments, as in the classical guitar and to offer solutions for working synchronously and actively with other fingers. The lack of mobility of the little finger compared to the other fingers due to the fact that we use it less naturally, except for playing the musical instrument. It is not possible for the little finger to be as strong as the other fingers due to its structural differences compared to the other fingers. The aim is to reduce the difference in strength and mobility between the fingers. Another aspect of this study is to minimize these problems and to pave the way for a faster way in this regard by enabling the musician to recognize his own anatomy, become aware of his finger muscles, and perform unique exercises and exercises related to these problems, which are frequently encountered in musical instruments played with the effective use of hands and fingers is the purpose.

Each of our fingers, which differs anatomically and developmentally, has different movement abilities depending on their specific muscle structure and strength. While these differences are rarely positive when playing a musical instrument, they are often a problem. It is a soughtafter feature for the instrument that all fingers used have equal strength and mobility. The little finger of a player who has not done any work on this subject is weak and quite dysfunctional in terms of micro-muscle movements. In this study, an answer is sought to the question of how to gain the required and desired mobility of the little finger, which is dysfunctional in terms of playing an instrument.

An active little finger, which is needed in almost all works in the classical guitar repertoire, has been a subject that should be considered 
by all guitarists. There are hardly any guitarists who do not have problems with their little finger. This problem also applies to other instruments. Doing special studies and exercises about the little finger is an inevitable necessity to play the pieces well. These subjects are also included in some classical guitar methods. It can be said that studies on strengthening the little finger and increasing the mobility are frequently included within the scope of technical studies in the education-teaching processes at the undergraduate, graduate and artistic proficiency levels in the field of classical guitar throughout the world.

Developing the ability to use the fingers as independently as possible on the instrument has been a need for all instrument players. For those who play instruments professionally, this is a must. Many guitarists have turned to research on what should be done to solve this problem. Each player may have a unique study and exercise method, as well as training and exercise suggestions that may be beneficial for all musicians. In this study, conscious exercises performed by following the stages specified in the legato technique related to the little finger give positive results even in a short time. Considering that the development of muscle memory develops in direct proportion to repetition, as these exercises are performed periodically, the desired mobility of the little finger will increase and develop at the same rate. In the medium term, the musician will be able to respond to the need for active use of the little finger in works and will be able to meet the need for the little finger and legato technique. In the long run, the strength and movements of the musician's little finger will become a need-based autonomous skill. Traits such as control, strength and precision between the fingers will come close to being equal.

Every person who plays an instrument, both as a hobby and professionally, needs to do special exercises for these fingers in order to be able to use their fingers actively and efficiently. As with every finger, there are many working methods and exercises to give the little finger the necessary and desired abilities. Performing the works well is possible by increasing the potential skills of all fingers. Since each person has a unique perception, albeit with small differences, it is necessary to understand the skill desired to be acquired in the little finger well and in detail, and to work in this direction. The sizes, angles, nail structure and 
softness of the fingers also appear with slight differences from person to person. Evaluating these differences while taking the suggested steps in this study will provide a faster development. Working with the little finger by focusing on the legato sections in the works and repeating these sections slowly is another way to help solve this problem. It will also be productive to transfer the legato parts of the works to other frets and strings on the classical guitar. The behavior of playing a musical instrument, which is a psychomotor skill, is an endless development process based on repetition with a completely conscious awareness. In this endless development process, as musical abilities progress, the goal to be achieved progresses at the same rate. This tells us that we must always work. Musical people with the goal of progress should be aware of their own perception and potential and create original studies and exercises for the problems they experiences. As a result, in this study, a quick and effective solution to this problem, which can be applied to every finger, but experienced in the little finger, is given. It is possible for each player to create their own small differences according to their anatomical and perceptual characteristics and to increase the efficient effect of exercises on themselves.

\section{Kaynakça / References}

Ak, Ö. (2018). Müzik öğretmenliği klasik gitar öğrencilerinin bireysel çalgı (Gitar) performansı öz-yeterlik inançlarının çeşitli değişkenler açısından incelenmesi. (Yayımlanmamış Yüksek Lisans Tezi). Eğitim Bilimleri Enstitüsü, Müzik Öğretmenliği Bilim Dalı, Marmara Üniversitesi İstanbul.

Araboğlu, T. (2011). Viyolonselde yay tutuş tekniği ve temel yay teknikleri: Legato, Detashe, Staccato ve Spiccato' nun incelenmesi. (Sanatta Yeterlik Tezi). Sosyal Bilimler Enstitüsü, Yaylı Çalgılar Sanat Dalı, Trakya Üniversitesi Edirne.

Chapman, R. (1993). Bütün yönleriyle gitarlar. Ankara. Dost Yayıncllık.

Chew, G. (2001b). Mad. Legato. S. Sadie ve J. Tyrrell (Ed.), The new grove dictionary of music and musicians (2. Bask1, cilt 14, 479). London: Macmillan Publishers. 
Çoban, S. (2019). Piyanoda artikülasyon tekniklerinin öğretiminde öğretmenlerin karşılaştıkları güçlükler ve bunlarla baş etme yolları: Güzel sanatlar liseleri örneği. (Yayımlanmamış Yüksek Lisans Tezi). Eğitim Bilimleri Enstitüsü, Müzik Eğitimi Bilim Dalı, Bolu Abant İzzet Baysal Üniversitesi Bolu.

Elmas, Y. (1994). Sorularla gitar. İstanbul: Pan Yayıncilı.

Halvaşi, A. A. (1999). Ülkemiz müzik eğitimde klasik gitar. (Yayımlanmamış Doktora Tezi). Fen Bilimleri Enstitüsü, Müzik Eğitimi Anabilim Dalı, Marmara Üniversitesi İstanbul.

İzci, M. (2019). Düzenli piyano çalan konservatuvar öğrencilerinde elin antropometrik özellikleri, esneklik ve kas gücünün değerlendirilmesi. (Yayımlanmamış Yüksek Lisans Tezi). Sağlık Bilimleri Enstitüsü, Anatomi Anabilim Dalı, Üniversite Şehir.

Kasar, M. K. ve Yöndem, S. (2006). Muğla Üniversitesi öğrencilerinin klasik gitar ile ilgili bilgi ve tutumları. Muğla Üniversitesi Sosyal Bilimler Enstitüsü Dergisi. 16, 54-71.

Kim, S. J. (2002). Touch and articulation on the organ: Historical and pedagogical perspectives. (Yayımlanmamış Doktora Tezi). Hugh Hodgson School of Music, The University of Georgia USA.

Uluocak, S. (2011). Klasik gitar tarihi-I. İstanbul. Doruk Yayımclık.

Uluocak, S. (2015). Türkiye'de Cumhuriyet'in ilk elli yılında klasik gitar eğitimi: paleologos ve öğrencileri. Hacettepe Üniversitesi Ankara Devlet Konservatuvarı Sahne ve Müzik Eğitim-Araştırma Dergisi, 1, 6080.

Yöndem, S. (2003). Anadolu güzel sanatlar lisesi gitar lise hazırlık kitabl. İstanbul: M.E.B. Devlet Kitapları.

\section{Kaynakça Bilgisi / Citation Information}

Özdağ, O. (2021). Klasik gitarda sol el serçe parmağı ile legato tekniği üzerine bir değerlendirme. OPUS-Uluslararası Toplum Araştırmaları Dergisi, 18(40), 2853-2867. DOI: 10.26466/ opus.873382. 